\title{
A Comparative Study of The Yorùbá News and Aláròyé Newspapers
}

\author{
Adefemi Akinseloyin \\ Department of Linguistics and African Languages \\ University of Ibadan, Nigeria \\ femiseloyin@gmail.com
}

\begin{abstract}
The Yorùbá News, since its inception in 1924, was an admiration to many. Its informative function, which covered variety of fields relevant to the grassroots, cannot be overlooked. Despite the series of scholarly writings on The Yorùbá News, much work has not been geared towards a comparative study of the newspaper with any other be it old or contemporary. In the light of this, this essay therefore attempts a comparative study of The Yorùbá News and Aláròyé, a fast-selling contemporary Yorubá newspaper. Four editions of The Yorùbá News and two editions of the Aláròyé newspapers are selected and content-analyzed using postmodernism theory. It is observed that The Yorùbá News distanced itself from aesthetics and total bias to the grassroots while Aláròyé newspaper foregrounded aesthetic splendor and grassroots biases in its editions. In this study, language, content, and headings/headlines are employed as measures of our comparison.
\end{abstract}

\section{Introduction}

Yorùbá newspaper, which is an example of mass media in print form, is a primary means of communication that is intended for the consumption of the mass audience. Essentially, the functions of Yorùbá newspapers are to inform, educate, and entertain. The entertainment content is contained in columns like puzzles, games, cartoon strips, and other humorous or satirical writings. The widespread information in Yorùbá newspapers intimate members of the public with societal happenings, events, and governmental plans of their immediate environments and the world in general in indigenous language for better comprehension. The language and culture of the Yorùbá people are also of crucial essence as publishers tend to promote both in their respective 
publications. Yorùbá newspapers, like other periodicals, are printed in large quantities on a daily or weekly basis and are relatively offered at affordable costs. Generally, newspapers are funded solely through paid subscriptions and advertisements, and to a lesser extent, by the cover prices that are indicated on its cover pages.

Publishing in Nigeria was pioneered by the Christian missionaries. This was initiated by the establishment of the first printing press by the Presbyterian Mission at Calabar in 1846. Henry Townsend followed in 1859 by establishing İwe Irò hin, the first newspaper in Nigeria. His press was located in Abeokuta. ${ }^{1}$ Thus, nineteenth century marked the birth of formal publishing in Nigeria and this was pioneered by newspaper publications. As Akangbe (2014) remarked, "two other publications also came out in the nineteenth century. These were Iwe Irohin Eko in 1888 by A.M. Thomas and Iwe Eko in 1891 by Rev. J. Vernal" (66). Many other Yoruba newspapers followed in the early twentieth century, which included Nigbati Owo Ba Dile, - the Yoruba version of In Leisure Hours - a bilingual published monthly by two female missionaries at the CMS Bookshop in Lagos in 1910; Eko Akete by Adéoyè Deniga in 1922; Eleti Ofee by E.A. Akintan in 1923; Eko Igbẹhin by E.M. Awobiyi in 1926, and Akede Eko by I.B. Thomas in 1927; among others (Akangbe, 2014:67). In the latter part of the twentieth century, emerged prominent Yorubá newspapers like Gboungboun, published by the Daily Sketch Press Limited in Ibadan; İsọk kan, published by the Concord Press of Nigeria in Lagos; and İroyin Yorubá, published by the African Newspapers of Nigeria.

It must be mentioned that with the innovations in technology, most of the Yorùbá newspapers now have their own websites to disseminate major news items to their readers electronically at large. This has been extensively discussed by various scholars and critics of Yorùbá newspapers which include Akinfeleye (1985, 1987), Duyile (1987), Salawu (1993, 2001, 2004a and 2004b) and Osunnuga (2001 and 2013). Through their scholarly works, these authors have discussed the origins of Yorùbá newspapers, their thematic pre-occupations, content, reviews, language, and challenges. We are not aware of the comparative study of Yorùbá newspapers, especially between the colonial and post-independence newspapers. Hence, the concern of this study is to attempt a comparison of The Yorùbá News (1924-1945) published by Denrele Adetimikan Obasa and Aláròyé newspapers (1985-to date) published by Musa Alao Adedayo.

1 Salawu, A. "A Study of Selected Vernacular Newspapers in Nigeria". Unpublished Master in Science project, University of Lagos, Lagos (Nigeria), 1993. 


\section{Overview of The Yorùbá News and Aláròyé newspapers}

The Yorùbá News was a weekly bilingual newspaper printed by the İlàrẹ Printing Press and was edited by its founder, Dén'relé Adétimí kàn Obasá. It was based in Ibadan. And was indeed the first printing press in Ibadan. His choice of language, Yorùbá and English, gave the newspaper a widespread approval and acceptance as it serviced the interests of both the natives and elite of that time. The newsprint started publication in 1924 and was part of the second wave of indigenous language press publications. The editor and founder of The Yorùbá News employed the newspaper as a social weapon to promote Yorùbá language, orature, and culture.

Aláròyé, on the other hand, is a weekly newspaper published solely in Yorùbá language by World Information Agents - the publishers of Alároyé, Akédé A'gbayé, Alároyé Magasí ini, and Iríri Ayé. The newspaper has helped sustained the reading and speaking of Yorùbá language through investigative and balanced journalism. The first edition of Alároyé was published in 1985 and lasted a few editions as a result of financial constraint. The second attempt in 1990 also did not last long because it did not get to the vendors. Little success was recorded on Aláròyé in 1994 before it was faced with another financial challenge. Aláròyé therefore went through a planned revolution, resurfaced in July 1996. Till date, it is still active in circulation with sales figure of over one hundred and fifty thousand copies per week. The success of Aláròyé is notable for its unique writing and reporting styles.

\section{The Yorùbá News and Aláròyé Compared}

Our yardsticks for comparing The Yorùbá News and Aláròyé will be the language and style, content, and the headlines/headings of the two newspapers.

\section{Language and style}

Language is paramount to mass media, especially newspapers, because language is the vehicle of communication. This is why scholars assert that language, in a broader sense, is the method of communication because it represents ideas and concepts that exist independently of, and prior to, language (Lyon, 1981; Bett, 2010). Newspapers have their own language and linguistic features for informative, expressive, phatic, directive, and aesthetic functions. This accounts for why journalists convey the essential part of the news in an economical way to present their thoughts to their readers, listeners, or audience.

The language use in The Yorùbá News was bilingual while that of Aláròyé is monolingual. The Yorübá News came at the era where Western education was being introduced to the continent of Africa. Therefore, the content of the newspapers was targeted at both the elite and those without formal education. Since there were limited newspapers then, and the distance between zones 
and regions in Nigeria were long, employing bilingual would not only capture both the natives and elite, it would also ensure a wider reach for higher number of readers. Aláròyé, however, emerged at a time when there are several flourishing newspapers in English with very few Yorùbá newspapers in existence. The newspaper therefore was a product of corporate determination to sustain the ailing Yoru bá newspaper industry and, by so doing, preserve the language and culture of Yorùbá. This puts Aláròyé in total allegiance to the grassroots as it makes information accessible to them in their mother tongue. Standard language which aids effective communication between the encoder and decoder dominates The Yorùbá News as the newspaper fulfils its primary role of informative functions.

It is observed from the selected issues of The Yorùbá News consulted for this research that general news about the activities of the government and their projects were written in English while local news were rendered in Yorùbá. In the February 2, 1926 edition of the newspaper, the following topics were written in English: "Nigerian Itinerary of the Honourable W. Ormsby-Gore", "Funeral and Memoirs of C.A. W. Pratt Deceased", and "A Last Word on West African Segregation" while "Òwúyẹ", "İfinijoyè ní İjọ U.N.A", and "A Mbẹru Alaja" were written in Yoruba. It is observed also that the topics written in English in the February 25, 1936 and September 13, 1938 editions of The Yorùbá News bothered on general news while the ones written in Yorùbá are more of creative writings targeted at the native speakers with no formal education to entertain and sensitize them on their societal happenings. The editor of The Yorùbá News employed the use of day-to-day conversation or formal language in the newspaper prints with the consciousness of the 1875 orthography rules. There were few instances where proverbs were employed to add meaning to the reports. For example, in "Onilu oro abi onilu ole", the publisher employed the use of proverb "ó jọ gàté, kò jọ gàté, ó f'ẹsẹ mejeji tiro" to draw the attention of those in authority to the activities of the night drummers and the issue of robbery cases at night. He wrote:

Hẹn-ẹn! Ó jọ Gàté, kò jọ Gàté, ó f'ẹsẹ mejeji tiro. A nri oye pe, lẹhin ọjọ melo kan ti awọn alu-gangan oru wonyi ba ti wa si adugbo kan ni a ma ngbọ pe ọlọsa ko ile lọ nibẹ. Ewo l'ewo? Onilu orò tabi Onilu ole. Ọrọ yi nfẹ amojuto lọdọ ẹnyin Alaṣe ilu. E gbani kalẹ o! $!^{2}$ (The Yorùbá News, $13^{\text {th }}$ September, 1938).

Really! It's more than a coincidence. We observed that few days after the midnight gangan drummers visit an area, such area was usually robbed. What do we call this? The bullroarer drummer or a thief. This needs a special attention from the appropriate quarters. Save us!

2 The text is deliberately not tone-marked so as to retain its original format. We decided not to rewrite or tamper with text so as to reflect how it was originally written. This, we feel, will make a strong historical statement about Yoruba publications of old. 
Such instances may not be missing as we know that proverbs are employed to give meaning to a subject matter among the Yorùbá people.

Aláròyé, on its part, has superfluous use of literary language which accentuates the creative ingenuity of the writers/editors and, thereby, asserts the aesthetic function of the newspaper. Aláròyé employs the superfluous use of proverbs and other figurative expressions such as simile, hyperbole, and euphemisms. In the language usage, it is observed that while the language use in The Yorùbá News was simple, straight, and direct, Aláròyé employs the use of humor in its presentations. This is a strategy to arrest the minds of the readers. Aláròye orthography largely conforms to that of the most recent 1974 orthography but it is worthy of note that the newspaper does not add diacritics or tone-mark its text at all. When this writer recommended to the publisher of Alároyé to consider the usage of tone a few years ago, he was told that tone-marking the texts would affect the layout while printing. The excuse was shocking and disturbing, one wonders how published books in Yoruba language are printed with tone-marks today without affecting the print layouts.

Code-switching or code-mixing are not found in the selected newspapers for this study in whatever form. Where there should be an occurrence of such, loan words are employed in conformity to the rules of the target language. It must also be emphasized here that the linguistic creativeness used in Aláròyé to invent or coin new words is worthy of emulation as it helps to promote the development of Yorùbá Language.

\section{The Content}

Since news is primarily about happenings and events in the readers' immediate and remote environments, there are justifiable reasons, therefore, for overlapping topics in the existing newspaper. Infact, we see cases of same content but with different styles of writings and reporting from today's numerous daily and weekly newspapers. The content of any newspaper revolves around the day-to-day activities of the people, hence, cases of topical issues, such as religious activities, politics, agriculture, etc., are common. This corroborates Sadaf's (2011) view that the "media act according to the circumstances and situations, it likes to support specific point of view on some issues and this is all done because media is the vigilant pillar to provide basic and instant news coverage on all aspects" (21). Though the two newspapers have similar cases of the mentioned issues as parts of their contents, nonetheless some differences are spotted and highlighted.

The Yorùbá News had more of the topical issues on colonization and activities of the colonial masters. This was actually because the newspaper thrived during the Nigerian pre-independence era with the domination of the colonial white masters in almost all spheres of governance and economy. Agriculture, crime, religious, and monarchical issues were also given prominence 
in the contents of the news. One of the indigenous professions of the Yorùbá people is farming and this was well harnessed to the country's advantage in the pre-independence era and for the first two decades of the post-independence period. The effect of this is seen in various constructions embarked on by the government of the then Western Region of Nigeria. Some of these landmark projects embarked upon by the then Western Nigerian government are the Cocoa House complex, Liberty Stadium, University of Ife (now Obafemi Awolowo University, Ile-Ife), the Western Nigeria Television (now Nigerian Television Authority, Ibadan), free education programme, etc. The period in question was a period of agricultural boom and colonial governance. On the cover page of the edition of The Yoruba News, readers were intimated with the prospects of cocoa.

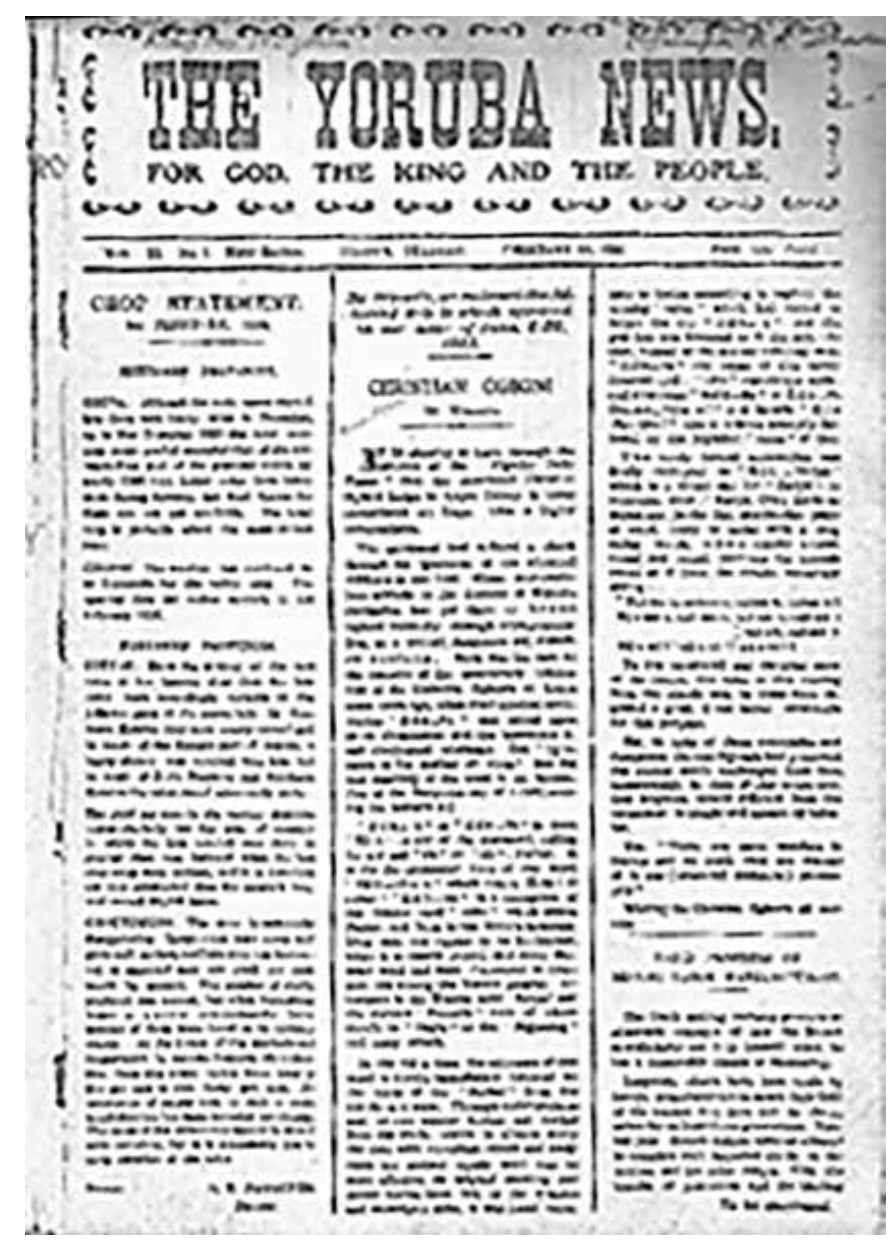

Yorùbá News, February 25, 1936>

In The Yorùbá News (especially the ones considered in this study), there is no mention of the issue of the oil boom and other challenges associated with it 
because oil had not been discovered in Nigeria anyway. In the case of Aláròyé however, contents are more about the recurring happenings in the Niger-Delta region. This emphasizes the fact that premium was placed on agriculture in Nigeria before pre-independence, compared to the current dispensation when all we think and depend on is oil.

\section{3}
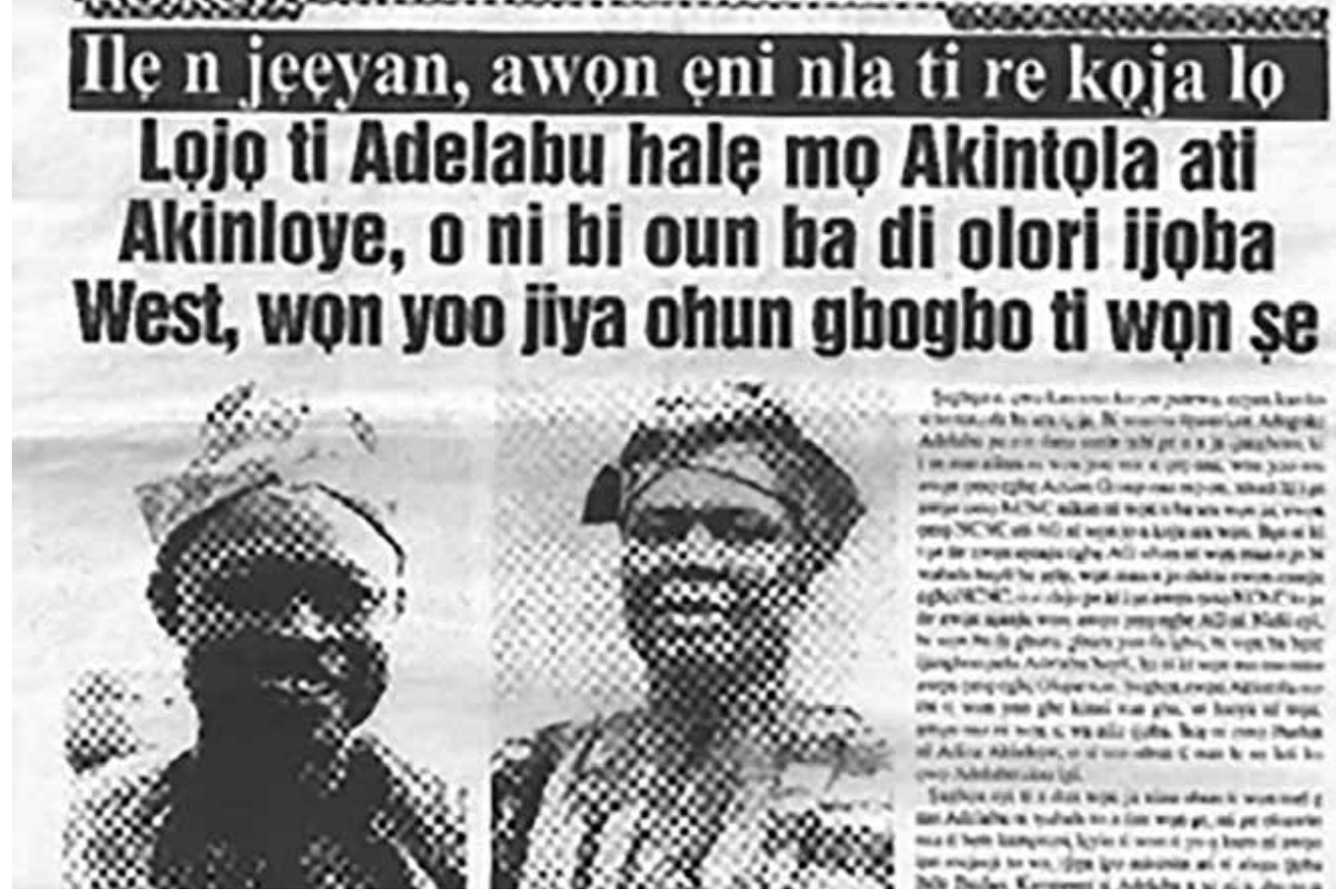

Aláròyé, February 25, 2014

Conversely, Aláròyé features more topical issues especially on politics, religion, history and other societal happenings. A session on historical allusion in Aláròye is worthy of note. References are usually made to historic moments, especially in Nigerian political spheres through the use of stories that captivate the readers. Legendary personalities and incidences are given prominence in Aláròyé as a nostalgia to recall memorable feats and occurrences which impacted on the Yoruba nation. A relevant example is drawn from the November 14, 2017 edition of the newspaper with the caption: "Ile $\mathrm{n}$ jẹeyan, awọn ẹni nla ti re koja lọ" (Earth consumes human! The mighty have passed away). The story, tagged, "Ọrọ dija n’Ibadan lọjọ ti wọn n ko Eggbẹ Ọmọ Ọlọfin jade, l'Akintọla ba binu rangbọndan" (Crises erupted in Ibadan during the inauguration of Omọ Olọin Society as Akintọla fumed). This session makes referefence to the political atmosphere of the post-independence era. The news are thought-provoking as they bring our consciousness to some mishaps and failings in our society such as misdemeanor, leadership excesses, 
parental irresponsibility, socio-economic neglects, ritual killings, etc. Aláròyé is a monthly publication so there is enough time for both the reportorial and editorial teams to conduct research, peruse content, write creatively, and plan for the next edition. Comparatively, The Yorùbá News had less articles on crime rates unlike Aláròyé which features many articles on criminal activities in the society. This draws our attention to the increase in crime rate these days compared to the pre-independence era.

\section{Advertorials}

Another topc that is worthy of mention is the advertorials in the selected newspapers. Stanton (1984) sees an advert as a form of marketing (being paid for and controlled by the advertiser) which employs a non-personal message to sell or promote product, service, or idea. The target audience of an advertisement is not narrow but broad since it is directed at any interested populace. Media houses, especially in the current dispensation, obtain a greater percentage of their earnings from proceeds from advertorials in their newspapers, on radios or television and the position or page of adverts determines the price. Advert is a common feature of The Yorùbá News and Aláròyé. Most of the advertisements in The Yorùbá News center on agriculture, engineering, traditional medicine, trade and general merchants. These adverts are about two to three pages in small sizes. Adverts in Aláròyé are similar to those in The Yorùbá News but with a difference. As a result of the consumers' improved awareness, enlightenment and digitalization, Aláròé enjoys the patronage of industries, small-scale businesses, and individuals, hence reasons for appealing adverts. 


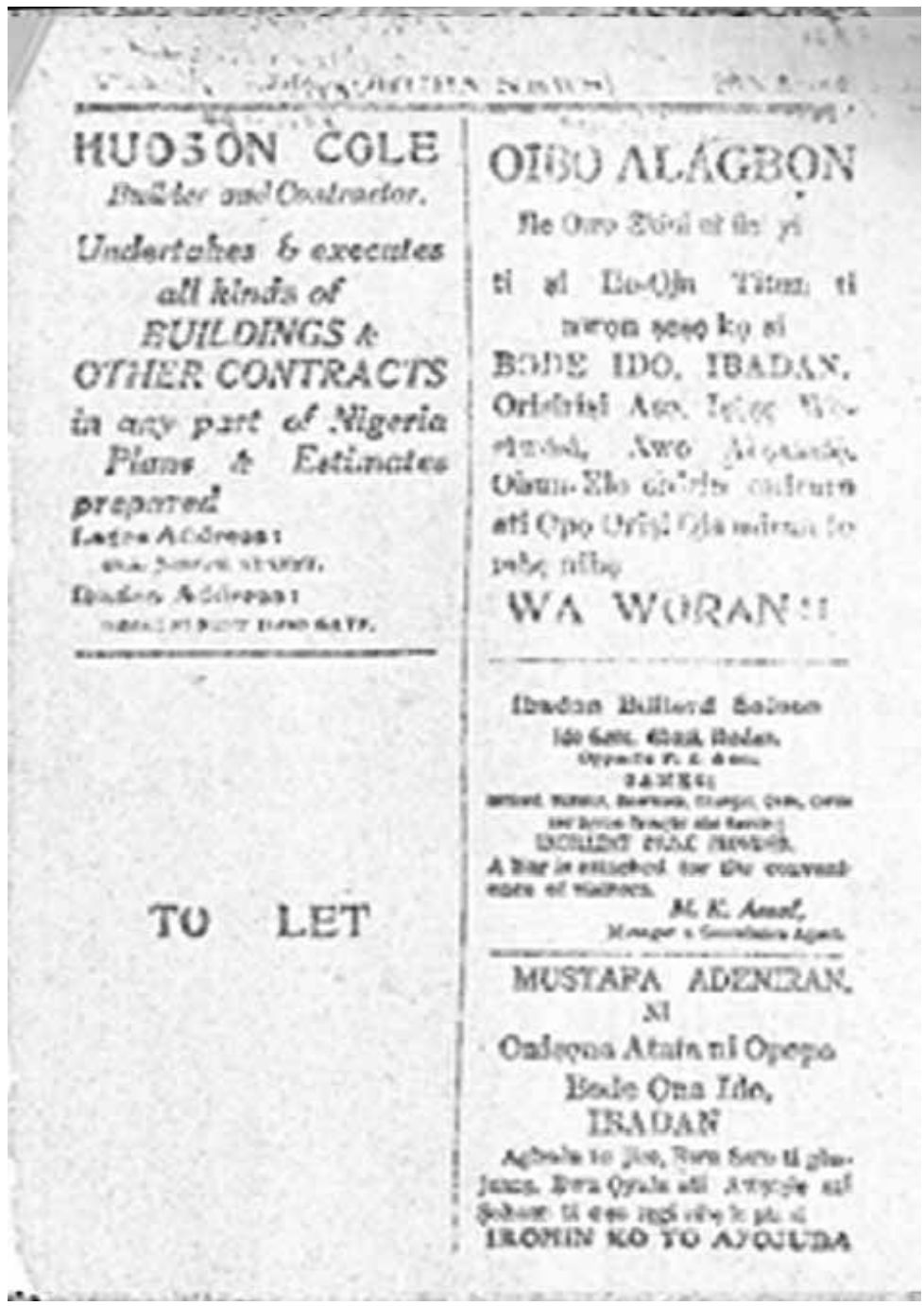

Yorùbá News of February 2, 1936> 


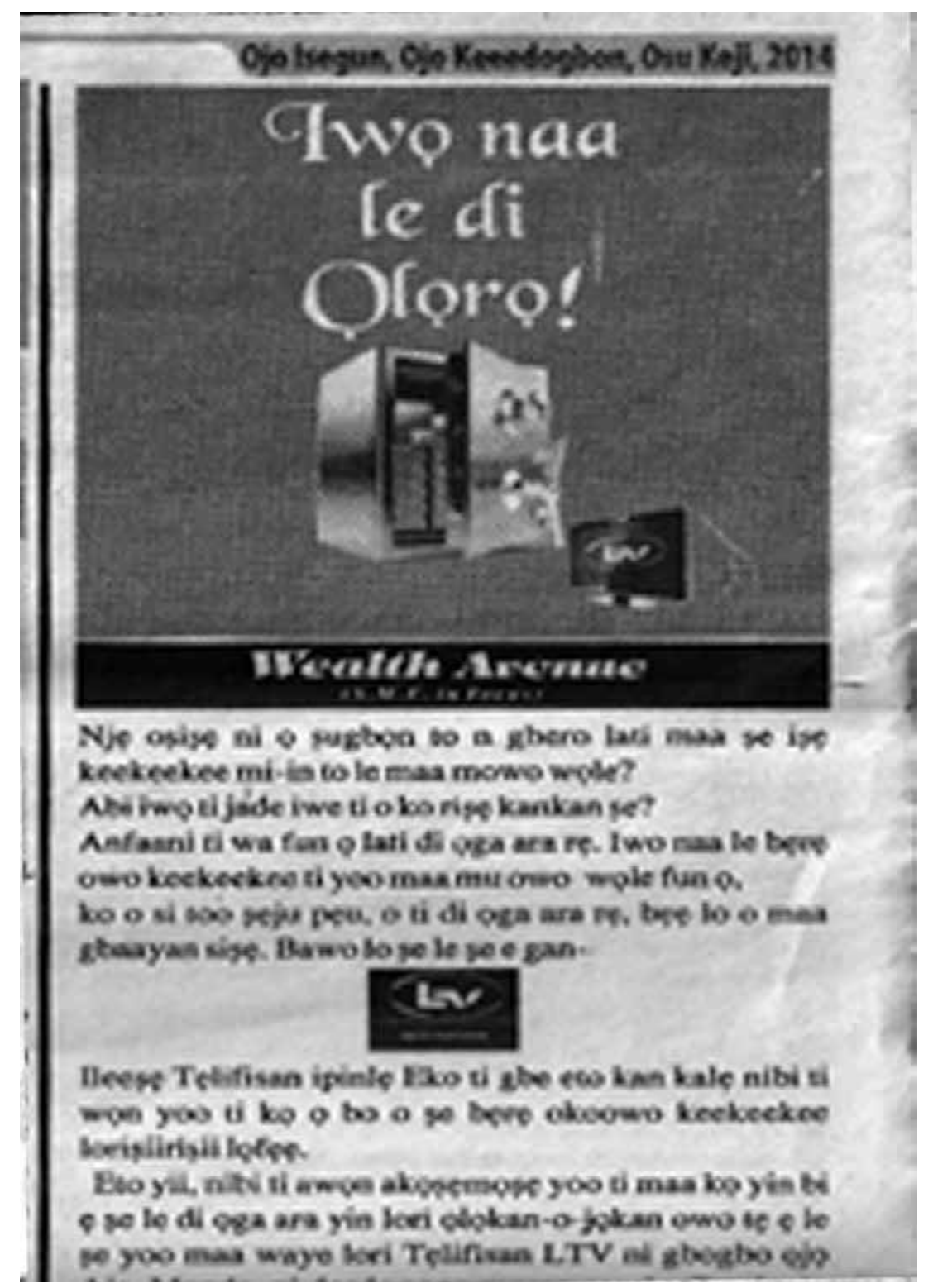

Aláròyé of February 25, 2014

This is made possible through the use of colors, images and pictorials which define the products and convey other relevant messages depending on the type of advert. The Yorùbá News use the arrangement of texts to convey its message without any form of appealing designs as seen in the example above while Aláròyé employs good graphics in its adverts.

The sharp difference in the quality and quantity of adverts in the two newspapers is occasioned by awareness imposed by time, development, modernity and technology, among others. As seen in the above examples, technology has an impact on the production of the newspapers, which in turn appeal to readers appeal of the newspaper. The contrast in the adverts shows the dearth 
of technology in Nigeria at the time of the print of The Yorùbá News. Graphics, especially colors and images, also help to convey the intended message of an advert. Full colored adverts are more attractive and appealing, they communicate more effectively, and bring more revenue to the newspaper houses. As a matter of fact, the number of adverts a newspaper is able to attract goes a long way in determining its economic success. The economic success is in turn indicated by the percentage of full color adverts and the sizes of such adverts in a newspaper. Advertorials is therefore a major index of good performance for a newspaper.

\section{Headlines and Headings}

Headlines are texts indicating the nature of the article under it and its main thrust is to briskly draw attention to the story. Headlines and headings are used as baits to attract, engage, and retain the readers' interest in the content as summed up below.

$\mathrm{H}$ - Heralds the day's news; tells what is of importance.

E - Entices the reader with essential or interesting facts.

A - Advertises the most important story by size or placement on the page (the most important stories are displayed at the top of the page).

D - $\quad$ Dresses up a page with typography; helps make design attractive.

S - Summarizes the story with a "super" lead; tells what the story is about. $^{3}$

The reader should be able to pick up the focus of the news with a quick glance at the headlines and other headings (sub-sections). With the illustration and explanation, it is not a fallacy to assert that headlines and headings play important role in mass media and news dissemination.

It is observed that the headlines and headings in The Yorùbá News were precise and bare as they were usually presented in common font sizes, which hardly differed from those of the body texts; unlike those of Aláròé which are bold, brave, and gallant. The font type and sizes are carefully chosen to display command, invite appeal, and compel attention. For instance, the front pages of The Yorùbá News were not as bold as that of Aláròyé. The February 2, 1936 and August 5, 1930 editions had adverts on the cover page while Aláròyés front pages are embellished with arresting headlines. The arresting headlines are written in daring bold letters and big point sizes. Selected headings in The Yorùbá News include: "A Last Word on West African Segregation", "A Dangerous Pit" and "Isin Ikore Ijọ U.N.A, Ijaiye" in the 1926 edition; "The Scourge

3 http://www.tpub.com/journalist/82.htm 
of Unemployment in Nigeria" and "Egbẹ Séráfù" in August 5, 1930; "Christian Ogboni", "The Passing of King George V" and "Egẹ D'Orișa" in February 2, 1936 edition; "The W.A.S.U. and African Education", "To Our Obas" and "Jericho N'Ibadan" in September 1938 edition. The headlines already give us the expected content.

Headlines and headings from Aláròyé include "Wọn mu baalẹ to fẹe ji maaluu l'Eruwa", "Ẹni to ba gba ọmọ mi sọdọ yoo ku lojiji", "Ambode ti ile Ọnarebu Tẹjuosho pa n'Ikẹja”, "Oga meji ninu ọkọ kan naa: PDP dibo yan alaga meji nipinle Oyọ", "Ole ti mo ja ni mo fi n sanwo ileewe mi - Omọ Poli", "Olọkada pokunso n'Ibadan nitori to sopa" in the November 14, 2017 edition. Headlines in February 25, 2014 edition include "Wọn ti Iya Wolii sẹwọn l'Ondo, ofin imototo lo tapa si", "Nitori ibo 2015: Jonathan dọbale fawọn Ọba Yorùbá - O ni ki wọn șatilẹyin foun", "Ki i șe ori eeyan lawọn ọlọpaa ba lọwọ mi, fufu ni mo fi mọ ori yẹn, jibiti lasan ni mo fi n lu n'Iware." Though, these headlines are also direct but they are humorous in presentation and dramatic in tones. They are surely more capitvating than those cited earlier from The Yoruba News.

On a note of comparison, the headings and headlines of The Yorùbá News are less appealing while those of Aláròyé are more attractive, more appealing, and reader-friendly with the kind of news they carry and the embellishment of their design. However, the simplicity of the headings of The Yorùbá News made it easy to read as the reader understood the content of such headings readily. The intrepid headlines and headings in Aláròyé attract and arrest the readers' attention, thereby, compelling him/her to go through the content of the news. The assertiveness wins the heart of many as they are complemented with good graphics to attract the readers' attention. Many times, people become inquisitive with the pictures and headlines and thus buy the newspaper to peruse the content. This is achieved through the effective use of illustrative elements such as drawings, photographs, pictures, maps, etc. garnished with inviting colors and elevated graphic designs.

\section{Conclusion}

From our discussion so far, it has been established that The Yorùbá News as a newspaper adequately performed its informative functions through its content and form while Aláròyé extends its functions to aesthetics. The aesthetic prowess of Alaroye supports its grassroots bias as it presents stories in an appealing mode to the common folks. Our indices of comparison were language, contents, and headings/headlines. Since the two newspapers belong to different age and era, it is expected that there would be notable differences. In this, Aláròyé is seen to have gone through discontinuity and variance. This, in 
many ways, have great impact on the demands of the newspaper amidst the thriving English newspapers. The color combinations, effective illustrations, and efficacious narrations are complimentary to Aláròyé, and these characteristics obviously make the newspaper more attractive and appealing than The Yorùbá News.

\section{References}

Akangbe, C. A. "History, Production and Content of Atọ́ka Photoplay Magazine." An Unpublished doctoral dissertation, University of Ibadan, Ibadan (Nigeria), 2014.

Akinfeleye, R. A. "Religious Publications: Pioneers of Nigerian Journalism." In Mass Communication in Nigeria: A Book of Readings, Onuora Nwuneli, (ed.). Enugu: Fourth Dimension Publishing Co. Limited, 1985.

Akinfeleye. R. A. Essentials of Modern African Journalism: A Premier (2nd Ed). Lagos: Miral Printing Press, 1987.

Akinyemi, Akintunde. "Déńrelé Adéètìmíkàn Ọbasa (1927-1945) - Akéwì Aláròjinlẹ". An Unpublished Master in Arts project, Department of African Languages and Literatures, University of Ife, Ile-Ife (Nigeria), 1987.

Akinyemi, Akintunde. "D.A Obasa (1879-1945): A Yorùbá Poet, Culture Activist, and Local Intellectual in Colonial Nigeria." Africa Vol. 87, No. 1 (2017): 1-15.

Bett, R. "Plato and His Predecessors." In Concise Encyclopedia of Philosophy of Language and Linguistics, eds. A. Barber and R. J. Stainton, 569-70. Elsevier, 2010.

Bishop, Wendy and D. Starkey. "Postmodernism." In Keywords in Creative Writing. University Press of Colorado and Utah State University Press. www.jstor.org/stable/j.ctt4cgr61.30, 2006.

Duyile, D. Makers of Nigerian Press. Lagos: Gong Communications, 1987.

Lyons, John. Language and Linguistics. Cambridge: Cambridge University Press, 1981.

Olabimtan, Afolabi. "Language and Style in Obasa’s Poetry." In Yorùbá Oral Tradition: Selections from the Papers Presented at the Seminar on Yorùbá Oral Tradition: Poetry in Music, Dance and Drama, Wande Abimbola (ed.). Ile-Ife (Nigeria): University of Ife, 1985.

Ọșunnúgà, O. "Language Style of The Yorùbá Newspapers: Aláròyé as A Case Study. Unpublished Master in Arts project, University of Ibadan, Ibadan (Nigeria), 2001.

Òșunnúgà, O. "Investigating Ambiguity in Headlines of Contemporary Yorubá Newspapers.” Linguistics and Literature Studies 1(2) (2013): 61-65. 
Quinn, Edward. A Dictionary of Literary and Thematic Terms. New York: Infobase Publishing, 2006.

Sadaf, Ayesha. "Public Perception of Media Role." In International Journal of Humanities and Social Science, Vol. 1, No. 5. 2011.

Salawu, A. "A Study of Selected Vernacular Newspapers in Nigeria". Unpublished Master in Science project, University of Lagos, Lagos (Nigeria), 1993.

Salawu, A, "An Evaluation of the Development Communication Content of Yoruba Newspapers." An unpublished dissertation, University of Ibadan, Ibadan (Nigeria), 2001.

Salawu, A. "A Readership Survey of Yorùbá Newspapers for Development Messages." Journal of Social Sciences, 8(3) (2004a): 197-202.

Salawu, A. "The Yoruba and Their Language Newspapers: Origin, Nature, Problems and Prospects." Stud. Tribes Tribals, 2(2) (2004b): 97-104.

Stanton, William J. Fundamentals of Marketing. New York: McGraw-Hill, 1984.

\section{Newspapers}

The Yorùbá News. February 2, 1926.

The Yorìbá News. August 5-12, 1930.

The Yorùbá News. February 25, 1936.

The Yorùbá News. September 13, 1938.

Aláròyé. February 25, 2017.

Aláròyé. November 14, 2017. 